\title{
Model of Group Peer Assessment on E-Learning
}

\author{
K. O. Saputra ${ }^{*}$, P. A. Mertasana ${ }^{2}$, and P. Rahardjo ${ }^{3}$ \\ ${ }^{1,2,3}$ Department of Electrical Engineering, Faculty of Engineering, Udayana University \\ *Email: okasaputra@unud.ac.id
}

\begin{abstract}
Student motivation at class takes major role on achieving courses' learning outcomes. Multimedia based content, gamebased quiz, or self-assessment can maintain student interest to follow the learning process. Apart from the individual solution, working in group is one way to improve student motivation, however without proper arrangement, putting students in groups can degrade the competitive atmosphere of class, as less-smart students hang up to the more-smart students. Another alternative is implementing collaborative learning such as peer assessment that allows students to grade their fellows. However, objectivity between students must be concerned as students tend to give high-grade for their fellows. Combining group mode and peer assessment, this work proposed group peer assessment to improve student motivation on e-learning. Proposed method started by teacher open a group assignment on e-learning. Students then work on group to create solution. After the solutions are submitted, the extra-group peer assessment begins, where each group examines another group work. To maintain the objectivity of the peer assessment, final grade of each group obtained by combining grade from another group and grade from teacher. In the meantime, cooperation atmosphere in each group is maintained by intra-group peer assessment, where each member asses all his/her teammates in terms of intra-personal and inter-personal skills.
\end{abstract}

Index Terms - E-learning, Assignment, Peer-review assignment

\section{INTRODUCTION}

$\mathrm{L}$ EARNING outcomes of a course vary from technical aspects such as able to define, able to analyze, or able to design, to manner aspects like able to cooperate. Learning design of a course takes major role to students to achieve the learning outcomes. Collaborative learning has been used to design class in order to infuse both technical and manner aspects to students as they can work and discuss with their fellows in finding solution for a case in the course content. To enhance the degree of collaboration from horizontal direction to vertical, peer assessment is then implemented where students mark and comment the assignment of their fellows. Through peer assessment, students are given part of teacher rights that is to grade, where this authorization contributes analyzing and attitude skills to students as they must be able as fair as possible with as correct as possible when grading the work of their friends.

Nowadays, modern information and communication technology (ICT) have become part of daily life of students and teacher [1]. Therefore, the learning design of courses has also changed from conventional face-to-face only to a combination with ICT where learning management system (LMS) is used to design online formative assessment through quiz or rubric assignment, to form what so called as blended learning or electronic learning (e-learning). In some universities, e-learning is also used to provide fully-online courses where the in-class face-to-face is done through video conference fixture of LMS to create virtual classroom where students and teacher are placed at different locations [6]. LMS is getting able to mimic all conventional class activities to facilitate teacher to extend the learning design into modern fashion.

As collaborative learning through peer assessment is importance for student activity, it is a challenge for teacher to implement it on e-learning. Previous works have conducted online peer assessment through private developed information system. However, ability to implement online peer assessment through free LMS is also required to equally distribute quality learning design publicly. Among available open source and limited-free LMS, Moodle is the one that provide fixture for peer assessment namely as Workshop Activity [7]. However, Workshop Activity is only for basic version of peer assessment, where student can review and grade one or several students. It is worth nothing that peer assessment is contaminated by friendship bias where students tend to give high grade for their fellows, even when the peer assessment conducted in double blind form. To enhanced peer assessment quality, we proposed to form group peer assessment with involving teacher to grade both 
the submission and the collaboration between group members.

Proposed method started by teacher open a group assignment on e-learning. Students then work on group to create solution. After the solutions are submitted, the extragroup peer assessment begins, where each group examines another group' work. To maintain the objectivity of the peer assessment, final grade of each group obtained by combining grade from another group and grade from teacher. In the meantime, cooperation atmosphere in each group is maintained by intra-group peer assessment, where each member asses all his/her teammates in terms of intrapersonal and inter-personal skills. Objectivity of the intragroup grade is balanced using grade given by teacher for each group member. Grade from teacher is obtained by manual interview which then uploaded into e-learning. To date, there is no available LMS fixture to fully implement the proposed scenario. As a proof of concept, this paper utilizes fixtures of Moodle LMS to make the proposed method can be applied in real class.

The following section introduces the design of the proposed enhanced peer assessment. Finally, conclusion is presented in Section IV.

\section{Peer Assessment With Teacher And Group Grade}

\section{A. Type of Grade}

There are six type of grades resulted by the proposed scenario. The first two are Grade by group peer and grade by teacher for the submission by group. Let's named them both as Grade 1 and Grade 2 respectively. Grade 1 and Grade 2 are used to measure the technical aspects of students written on the work they submitted. Grade 2 is not directly given to group as this grade is only used to create Grade 3 . Grade 3 is grade given for groups for their assessment quality to another groups' work. Better quality means closer grade to the grade given by teacher. The other two grades are Grade by personal peer on group and Grade by teacher for every student for their activity in group. Grade 3 and Grade 4 are the name for those two grades. These two are used to measure the collaboration between students in each group. Grade 5 is not directly given to students as they are used to create Grade 6 , grade given to students for their assessment quality to theirs peers collaboration. Table 1 summarizes all these four grades.

Friendship bias often occurs on Grade 1 and Grade 4 where students directly give grade to other students. Therefore, to counterbalance the possibility of friendship bias, Grade 2 and Grade 5 are involved. Students as group or as personal will lose some points for Grade 3 and Grade 6 respectively if they inconsequent to give grades to their peer, both for on purpose or inability.
Table 1. Type of Grade

\begin{tabular}{|l|l|l|}
\hline $\begin{array}{l}\text { Grade } \\
\text { name }\end{array}$ & Description & $\begin{array}{l}\text { Marking } \\
\text { scheme }\end{array}$ \\
\hline Grade 1 & $\begin{array}{l}\text { Given to group based on } \\
\text { group submission graded by } \\
\text { another group }\end{array}$ & Rubric \\
\hline Grade 2 & $\begin{array}{l}\text { Given by teacher for the } \\
\text { submission by group }\end{array}$ & Rubric \\
\hline Grade 3 & $\begin{array}{l}\text { Given to group based on how } \\
\text { close Grade 1 to Grade 2 for } \\
\text { the same graded subject is }\end{array}$ & $\begin{array}{l}\text { Moodle } \\
\text { calculation }\end{array}$ \\
\hline Grade 4 & $\begin{array}{l}\text { Given by student to the other } \\
\text { students in a group }\end{array}$ & $\begin{array}{l}\text { Intra and } \\
\text { inter } \\
\text { personal } \\
\text { skill rubric }\end{array}$ \\
\hline Grade 5 & $\begin{array}{l}\text { Given by teacher to all } \\
\text { students }\end{array}$ & Interview \\
\hline Grade 6 & $\begin{array}{l}\text { Given to student based on } \\
\text { how close Grade 4 and Grade } \\
\text { 5 for the same student is }\end{array}$ & $\begin{array}{l}\text { Moodle } \\
\text { calculation }\end{array}$ \\
\hline
\end{tabular}

\section{B. Utilized Moodle Fixture}

Moodle LMS provides activities and resources for implementing online learning. To add course content such as presentation slides or pdf, File fixture is usually used. To put video to the course, Page fixture is added where in this fixture the embed link of the video is written, where the video is uploaded into cloud service such as YouTube or Google drive. For activity like formative assessment, Assignment fixture is used from teacher preparation, student submission, teacher comment and grade, to the student revision. Basic peer assessment is also accommodated by Moodle through Workshop activity. In Workshop, teacher started by creating assignment, followed by submission by students, continued with peer allocation, and then closed by grading mechanism.

To accommodate one full implementation of the proposed scenario, we utilized Workshop and Assignment fixtures of Moodle. Workshop in Moodle is not designed for group assessing another group submission. It is for person to assess person. There is group enabled mode on Workshop, but this is only to limit the peer assessment allocation only between students within a group. Grade 3, Grade 4, and Grade 5 can be obtained by utilizing one Workshop activity with enabled group mode. However, for Grade 1, Grade 2, and Grade 3, Workshop activity run in normal mode, but with manual arrangement where only one student is submitted to Workshop as a representation of his/her group. However, Grade 1, Grade 2, and Grade 3 are group grades where one grade is for all group members. Therefore, to be able to give group grade, Assignment fixture is lastly utilized as this fixture has group mode to deliver equal grade to all group members. In short, two Workshop activities and two Assignment activities are required to implement the proposed method in real online class activity. 
Table 2. Implementation Strategy

\begin{tabular}{|c|c|c|c|c|}
\hline Step & Fixture & Teacher & Student & Grade given \\
\hline 1 & Workshop 1 & $\begin{array}{l}\text { (1) Adding Workshop } \\
\text { activity } \\
\text { (2) Adding assessment } \\
\text { on Workshop } \\
\text { (4) Allocating peer } \\
\text { assessment } \\
\text { (5) Assessing submission }\end{array}$ & $\begin{array}{l}\text { (3) Submitting assessment by } \\
\text { student as representation of group } \\
\text { (5) Assessing another student } \\
\text { submission }\end{array}$ & $\begin{array}{l}\text { Grade } 1 \\
\text { Grade } 2 \\
\text { Grade } 3\end{array}$ \\
\hline 2 & & $\begin{array}{l}\text { Recording manually } \\
\text { Grade } 1 \text { and Grade } 3 \text { for } \\
\text { each representative } \\
\text { student from each group }\end{array}$ & $\begin{array}{l}\text { Creating revision from the } \\
\text { comment given by student and } \\
\text { teacher }\end{array}$ & \\
\hline 3 & Workshop 2 & $\begin{array}{l}\text { (1) Adding Workshop } \\
\text { activity } \\
\text { (2)Adding blank } \\
\text { assessment } \\
\text { (4) Allocating peer } \\
\text { assessment in each group } \\
\text { (5) Interviewing students }\end{array}$ & $\begin{array}{l}\text { (3) Submitting blank assessment } \\
\text { (5) Assessing other student } \\
\text { personal skill }\end{array}$ & $\begin{array}{l}\text { Grade } 4 \\
\text { Grade } 5 \\
\text { Grade } 6\end{array}$ \\
\hline 4 & Assignment 1 & $\begin{array}{l}\text { (1) Adding Assignment } \\
\text { activity } \\
\text { (2)Setting group } \\
\text { submission } \\
\text { (4) Assessing group } \\
\text { submission } \\
\text { (5) Manually calculating } \\
\text { grade from previous } \\
\text { Workshop 1 activity with } \\
\text { the revision grade } \\
\text { (6) Giving group grade }\end{array}$ & $\begin{array}{l}\text { (3) Submitting revision from } \\
\text { Workshop } 1 \text { activity }\end{array}$ & Grade 1 \\
\hline 5 & Assignment 2 & $\begin{array}{l}\text { (1) Adding Assignment } \\
\text { activity } \\
\text { (2)Setting group } \\
\text { submission } \\
\text { (3) Giving group grade }\end{array}$ & & Grade 3 \\
\hline
\end{tabular}

\section{IMPLEMENTATION STRATEGY}

There are five stages required to implement the proposed scenario. For instance, teacher gives an assessment on class, let say the task is to review an academic paper. On this point, students have been arranged into several groups and these groups have been set up as well on the LMS. For one task there will be four grades given to students: Grade 1 as the skill type grade; Grade 3 as the combination of skill and manner grade; Grade 4, and Grade 6 as the fully manner grade. The five stages of the implementation are detailed in Table 2.

The first stage is to announce the task. This announcement is placed into a Workshop activity, namely

Workshop 1. As students know that there is task to do, they discuss with their group to finish the task. Once the group has solution, they decide which student to become representation to submit solution to the Workshop 1. After all representative students submitted solutions, peer

assessment phase is then begun. Here, each group through account of their representative student access the allocated submission of other group. Students in a certain group assess the other group submission and then write the comments and the grade (Grade 1) on Workshop 1 through their representative student account. Along with peer assessment between groups, teacher mark each submission on Workshop 1 , to get Grade 2 as based grade to obtain Grade 3. After the assessment phase, Grade 3 is then calculated by calculating how close Grade 1 to Grade 2. The closer Grade 1 to Grade 2 resulted the higher Grade 3 and vice versa. As Grades resulted in Workshop 1 have not yet distributed to all students, then teacher has to manually record pairs of student and grade which will be used later at Stages 4 and 5. This manual activity occurs at Stage 2 of the scenario.

Along with the start of Step 1, Step 3 is also started. Another Workshop activity namely Workshop 2 is created. 
As Workshop on Moodle can be used for peer assessment only when there are submissions, so for Workshop 2, students must submit blank assignment, as this Workshop is used to assess intra and inter personal skills between students in a group that is not assessed through document but by personal inspection when they are collaborating. Workshop 2 used enabled group mode to bind the peer allocation only between students in a same group. Similar to Workshop 1, on Workshop 2 teacher must also give grade to students, but the grade is not for students' submission, but for results in interview. Grade 4 and Grade 6 are resulted in this stage.

After the peer assessment stages have finished, teacher then must compile the results of Stages 1 and 2 through Assignment 1 and Assignment 2 at Stage 4 and 5 respectively. Assignment 1 is used to put the final grade of Grade 1 after the revisions are graded by teacher. Assignment 2 meanwhile is just used to fill Grade 3 obtained from Stage 1. Assignment 1 and Assignment 2 are set with "Group submission setting mode on" to allow the grade are given to all member of the group.

Among all grades used in the proposed scenario, only Grade 1, Grade 3, Grade 4, and Grade 6 are used for assessment. These four grades then filled in the gradebook. The other two grades, Grade 2 and Grade 5, are used only for the purpose of obtaining Grade 3 and Grade 6 respectively.

\section{IV.CONCLUSION}

Combining group mode and peer assessment, this work proposed group peer assessment to improve student motivation on e-learning. Model of implementation scenario has been created. Future work will be how to implement on real class and evaluate how this scenario can improve learning design at class.

\section{REFERENCES}

[1] Iskandar APS, Sudarma IM, Saputra KO. Nonformal TestBased Gamification Model to Improve Student Motivation. Proceeding of the 2018 International Conference on Smart Green Technology in Electrical and Information Systems (ICSGTEIS). 2018; 215-220.

[2] Rujianto ES, Sazilah S, Zakaria MH, Anwar T. A gamification framework to enhance students' intrinsic motivation on MOOC. TELKOMNIKA Telecommunication Computing Electronics and Control. 2019; 17(1): 170-178.

[3] Mustikaningrum D, Retnowardhani A. Usability of BLESSimplemented class room: a case study of mixtio. TELKOMNIKA Telecommunication Computing Electronics and Control. 2019; 17(2): 703-711.

[4] Tessier D, Dalkir K. Implementing Moodle for e-learning for a successful knowledge management strategy. Knowl. Manag. E-Learning. 2016; 8(3): 414-429.

[5] Sadikin M, Yusuf R, and Arif Rifai D. Load balancing clustering on moodle LMS to overcome performance issue of e-learning system. TELKOMNIKA Telecommunication Computing Electronics and Control. 2019; 17(1): 131138.

[6] Darma Kotama in, Saputra KO, Linawati, Proposed Model of Multiplayer Matching Game Plugins Using Websocket in Moodle. Int. J. Emerg. Technol. Learn.. 2019; 14(11):
194-201.

[7] Linawati, N. Dewi Wirastuti, G. Sukadarmika, I. M. Arsa Suyadnya and D. C. Krishne, "Adaptive online learning design using moodle," 2016 International Conference on Smart Green Technology in Electrical and Information Systems (ICSGTEIS), Bali, 2016, pp. 98-101, doi: 10.1109/ICSGTEIS.2016.7885773.

[8]. G. Sukadarmika, R. S. Hartati, Linawati and N. P. Sastra, "Introducing TAMEx model for availability of e-exam in wireless environment," 2018 International Conference on Information and Communications Technology (ICOIACT), Yogyakarta, 2018, pp. 163-167, doi: 10.1109/ICOIACT.2018.8350741

[9] G. Sukadarmika, R. S. Hartati, Linawati, N. P. Sastra, D. M. Wiharta and M. A. Setiawan, "Proposed model for eexam availability in WLAN environment," 2016 International Conference on Smart Green Technology in Electrical and Information Systems (ICSGTEIS), Bali, 2016, pp. 89-92, doi: 10.1109/ICSGTEIS.2016.7885772.

[10] Garrison DR, Kanuka H. Blended learning: Uncovering its transformative potential in higher education. The Internet and Higher Education, 2004; 7: 95-105.

[11] Trenas MA, Ramos J, Gutiérrez ED. Use of a new moodle module for improving the teaching of a basic course on computer architecture. IEEE Transactions on Education. 2011; 54: 222-228

[12] Islam N, Beer M, Slack F. E-learning Challenges Faced by Academics in Higher Education: A Literature Review. Journal of Education and Training Studies. 2015; 3: 102112.

[13] Kampa RK, Kaushik P. Integrating the Library within the Moodle Learning Managament System: a Case Study. Journal of Library and Information Science. 2016; 6: 702711.

[14] Nagy J T. Using learning management systems in business and economics studies in Hungarian higher education. Education and Information Technologies. 2016; 21: 897917. 